\title{
Recombinant ob Protein Reduces Feeding and Body Weight in the ob/ob Mouse
}

\author{
David S. Weigle, ${ }^{\star}$ Thomas R. Bukowski, ${ }^{\ddagger}$ Donald C. Foster, ${ }^{\ddagger}$ Susan Holderman, ${ }^{\ddagger}$ Janet M. Kramer, ${ }^{\ddagger}$ Gerry Lasser, ${ }^{\ddagger}$ \\ Catherine E. Lofton-Day, ${ }^{\ddagger}$ Donna E. Prunkard, ${ }^{\ddagger}$ Christopher Raymond, ${ }^{\ddagger}$ and Joseph L. Kuijper ${ }^{\ddagger}$ \\ *Department of Medicine, University of Washington School of Medicine, Seattle, Washington 98195; and ${ }^{\ddagger}$ ZymoGenetics Corporation, \\ Seattle, Washington 98102
}

\begin{abstract}
To determine whether the product of the recently cloned $o b$ gene functions as an adipose-related satiety factor, recombinant murine $o b$ protein was administered intraperitoneally to $o b / o b$ mice. Monomeric $o b$ protein given as single morning injections to groups of three animals at seven doses ranging from 5 to $100 \mu$ g reduced 24-h chow consumption in a dose-dependent manner from values of $81 \pm 6.8 \%$ of control (10- $\mu \mathrm{g}$ dose, $P=0.04)$ to $29 \pm 7.7 \%$ of control (100$\mu \mathrm{g}$ dose, $P<0.0001$ ). Daily injections of $80 \mu \mathrm{g}$ of $o b$ protein into six $o b / o b$ mice for 2 wk led to an $11 \pm 1.6 \%$ decrease in body weight $(P=0.0009)$ and suppressed feeding to $26 \pm 4.9 \%$ of baseline $(P<0.0001)$, with significant reduction of serum insulin and glucose levels. The effect of recombinant $o b$ protein on feeding was not augmented by cofactors secreted by adipose tissue, nor did exposure of adipose tissue to $o b$ protein affect intracellular $o b$ mRNA levels. Posttranslational modification of $o b$ protein was not required for activity; however, addition of a hexahistidine tag to the amino terminus of the mature $o b$ protein resulted in prolonged suppression of feeding after injection into $o b / o b$ mice. These results demonstrate a direct effect of the $o b$ protein to suppress feeding in the ob/ob mouse and suggest that this molecule plays a critical role in regulating total body fat content. (J. Clin. Invest. 1995. 96:2065-2070.) Key words: satiety • appetite $\cdot$ obesity $\cdot$ adipose tissue $\cdot$ energy balance
\end{abstract}

\section{Introduction}

Obesity is a major public health problem that contributes significantly to cardiovascular morbidity and mortality in the United States and other developed countries $(1,2)$. Treatment of this condition is generally unsuccessful due to the operation of physiological mechanisms that restore adipose mass to baseline after intentional or unintentional changes (3-5). A particularly important mechanism acting to stabilize body fat content

Address correspondence to Dr. David S. Weigle, Division of Endocrinology, Box 359757, Harborview Medical Center, 325 Ninth Avenue Seattle, WA 98104. Phone: 206-223-3153; FAX: 206-287-8522.

Received for publication 31 May 1995 and accepted in revised form 10 July 1995.

J. Clin. Invest.

(c) The American Society for Clinical Investigation, Inc.

0021-9738/95/10/2065/06\$2.00

Volume 96, October 1995, 2065-2070 is the decrease in appetite and caloric intake that accompanies any increase in total adipose mass (6). In 1953 Kennedy postulated that this inverse relationship was due to a satiety signal transmitted by adipose tissue to feeding centers in the central nervous system (7). Hervey provided evidence for the presence of such a signal in the circulation of parabiotic rats (8), and Coleman demonstrated that defects in this signaling pathway could account for obesity in $o b / o b$ and $d b / d b$ mouse models $(9,10)$. Despite the plausibility of the Kennedy hypothesis, there has been only limited direct evidence for the production and secretion of a satiety factor by adipose tissue $(11,12)$.

The recently cloned cDNA of the mouse obese $(o b)$ gene encodes a 167-amino acid protein that is highly conserved in a number of vertebrate species (13). The presence of $o b$ gene transcript only in white adipose tissue, an amino-terminal signal sequence consistent with secretion of mature protein, and the hyperphagia of the $o b / o b$ mouse, which produces a defective $o b$ protein, has led to the suggestion that this protein may be the long-sought adipose satiety factor (14). However, the $o b / o b$ mouse also exhibits defects in thermogenesis, fat metabolism, insulin secretion, and fertility (15). To the extent that this pleotypic phenotype is explained by a defect in a single gene, the effect of the $o b$ protein on feeding may be indirect.

To determine whether the $o b$ gene product potentially acts as a satiety factor, we injected recombinant $o b$ protein intraperitoneally into $o b / o b$ mice and followed daily food intake and body weight. Decreased food intake was observed over a 24-h period with a clear dose-dependent relationship to administered $o b$ protein. Repeated daily injections of $o b$ protein led to weight loss and reductions in fasting insulin and glucose levels. The satiety effect of recombinant $o b$ protein appeared not to require any cofactor produced by adipose tissue, nor was posttranslational processing by a mammalian cell required for activity. The effect of modification of the amino terminus of the $o b$ protein to prolong its biological action was also explored.

\section{Methods}

Expression and purification of recombinant ob protein

Cloning of ob cDNA. Murine $o b$ cDNA was obtained by PCR of $d b /$ $d b$ mouse adipose tissue cDNA using primers designed from the terminal coding regions of the published cDNA sequence (13). A second round of PCR was used to add flanking EcoR1 and Sall restriction sites to permit directional insertion into the pDX expression vector (16) for transfection of BHK cells or into the pMAL-c2 vector (New England Biolabs, Beverly, MA) for transfection of Escherichia coli. Sequence analysis of the PCR product revealed complete agreement with the glutamine (+) variant of the published $o b$ cDNA sequence. An additional PCR reaction was used to add an in-frame tract of six histidine codons and a four amino acid spacer (GGSG) to the 5 ' end of the mature 
$o b$ coding sequence. A tissue plasminogen activator signal sequence was substituted for the native ob signal sequence to ensure proper processing and secretion. This PCR product was inserted into the pHZ-200 vector for expression of amino-terminal hexahistidine-tagged $o b$ protein in BHK cells. The pHZ-200 vector contains the mouse metallothionein-1 promoter and a cloning cassette flanked by the bacteriophage $\mathrm{T} 7$ promoter and both human growth hormone and bacteriophage T7 terminators. Additional elements of pHZ-200 include an E. coli origin of replication, a bacterial beta-lactamase gene, and a mammalian selection unit comprising the SV40 promoter and origin, a dihydrofolate reductase gene, and the SV40 transcription terminator.

BHK cell expression. BHK 570 cells (CRL 10314; American Type Culture Collection, Rockville, MD) were cotransfected with $16 \mu \mathrm{g}$ of pDX $o b$ and $4 \mu \mathrm{g}$ of ZEM229R (a plasmid encoding an expression cassette for the dihydrofolate reductase gene) by a modified calcium phosphate precipitation procedure (17). Transfected cells were selected for $12 \mathrm{~d}$ in medium containing $5 \%$ fetal calf serum and $500 \mathrm{nM}$ methotrexate. The surviving cells were pooled and transferred to $4 \mu \mathrm{M}$ methotrexate to further amplify the $o b$ gene. Pooled clones were used to seed 6,000- $\mathrm{cm}^{2}$ 10-layer cell factories (Nunc 70009; Nunc, Roskilde, Denmark). Upon reaching confluence, the medium in each factory was replaced with 1.5 liters of serum-free medium without methotrexate. Serum-free medium was composed of 50\% Ham's F12 medium and 50\% Dulbecco's modified Eagle's medium (both from GIBCO BRL, Gaithersburg, MD), $0.01 \mathrm{mg} / \mathrm{ml}$ fetuin (Sigma Immunochemicals, St. Louis, MO), $2 \mathrm{ng} / \mathrm{ml}$ selenium (Aldrich, Milwaukee, WI), $1 \mathrm{mM}$ sodium pyruvate (Irvine, Santa Ana, CA), and $0.01 \mathrm{mg} / \mathrm{ml}$ transferrin, 5 $\mu \mathrm{g} / \mathrm{ml}$ insulin, and $0.29 \mathrm{mg} / \mathrm{ml} \mathrm{L-glutamine} \mathrm{(all} \mathrm{from} \mathrm{JRH} \mathrm{Biosciences,}$ Kansas City, MO). After $48 \mathrm{~h}$ of conditioning, medium was recovered and concentrated 20 -fold using a $10-\mathrm{kD}$ hollow fiber ultrafiltration cartridge (A/G Technologies, Needham, MA). BHK 570 cells transfected with Zem229R alone were used to produce control conditioned medium. Concentrated conditioned medium was adjusted to $\mathrm{pH} 6.8$ in $5 \mathrm{mM}$ morpholinoethanesulfonic acid buffer and passed over a hydroxyapatite column previously equilibrated with buffer. The $o b$ protein was eluted with $10 \mathrm{mM}$ potassium phosphate buffer, $\mathrm{pH}$ 6.8, and visualized in SDS polyacrylamide gels developed with a Daiichi silver stain kit (Integrated Separation Systems, Natick, MA).

BHK 570 cells transfected with the pHZ-200 vector construct encoding amino-terminal hexahistidine-tagged $o b$ protein were selected in 1 $\mu \mathrm{M}$ methotrexate. Cells were grown to confluence in $10150-\mathrm{mm}$ tissue culture dishes, washed, and $15 \mathrm{ml}$ of serum-free medium without methotrexate was added per dish. After $48 \mathrm{~h}$ of conditioning, medium was recovered and concentrated 20 -fold by ultrafiltration over a $76-\mathrm{mm}$ YM1 membrane (Amicon, Beverly, MA). Tagged $o b$ protein was isolated by passing medium over a resin containing immobilized $\mathrm{Ni}^{2+}$ (HISBIND; Novagen, Madison, WI). Bound protein was eluted with 500 $\mathrm{mM}$ imidazole and dialyzed into PBS.

E. coli expression. The pMAL-c2 vector, designed to express its cDNA insert as a fusion protein with maltose binding protein (MBP), was introduced into E. coli MC-1061 (Clontech, Palo Alto, CA). Colonies of transformed cells were selected from LB ampicillin plates, and a clone with a verified in-frame MBP: $o b$ cDNA fusion was isolated. The clone was grown in LB broth containing $250 \mu \mathrm{g} / \mathrm{ml}$ ampicillin, and MBP: $o b$ fusion protein production was induced by $1 \mathrm{mM}$ isopropylthiogalactoside. Cells were harvested, disrupted by freezing and sonication and the fusion protein was recovered from crude cell extract by affinity chromatography on amylose resin. The fusion protein was cleaved with Factor $\mathrm{Xa}$ to liberate the $o b$ gene product and passed over a second amylose column to remove free MBP. Cleaved $o b$ protein was added

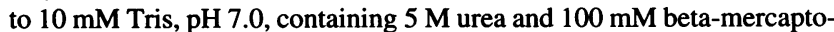
ethanol, and incubated at $50^{\circ} \mathrm{C}$ for $30 \mathrm{~min}$. The reduced unfolded protein was loaded onto a Vydac \#214TP1022 C4 column (Vydac, Hesperia, CA) and eluted with a $60-\mathrm{min} 27-72 \%$ acetonitrile gradient. The composition of purified $o b$ protein, which eluted at $47.6 \%$ acetonitrile, was confirmed by sequencing, mass spectroscopy, and amino acid analysis.

1. Abbreviation used in this paper: MBP, maltose binding protein
After lyophilization to remove acetonitrile, the $o b$ protein preparation was reoxidized to native form with a 20 -fold excess of Ekathiox resin (Ekagen, Menlo Park, CA) and dialyzed into Tris, pH 7.0.

\section{Detection and quantification of ob protein}

Antisera production. Rabbits were immunized by initial subcutaneous injection of $250 \mu \mathrm{g}$ of purified MBP:ob fusion protein in complete Freund's adjuvant, followed by booster subcutaneous injections every $3 \mathrm{wk}$ with $125 \mu \mathrm{g}$ fusion protein in incomplete Freund's adjuvant. Blood was collected $10 \mathrm{~d}$ after each booster injection, and serum was run twice over MBP-Sepharose columns (Pharmacia LKB Biotechnology, Piscataway, NJ). Antiserum was then purified by affinity chromatography over a 4-ml column containing $10 \mathrm{mg}$ of Sepharose-linked MBP: $o b$ fusion protein. The resulting purified anti-ob serum at a concentration of $2 \mathrm{mg}$ protein $/ \mathrm{ml}$ was demonstrated by Western analysis to be devoid of antibodies to MBP.

Western analysis. Test samples containing $o b$ protein were subjected to SDS polyacrylamide gel electrophoresis under reducing and nonreducing conditions and electroblotted onto nitrocellulose at $40 \mathrm{~V}$ overnight. Blots were exposed to purified anti-ob serum for $1 \mathrm{~h}$, washed, and then incubated in goat anti-rabbit immunoglobulin conjugated to horseradish peroxidase for $1 \mathrm{~h}$. After a final wash, protein bands were visualized by chemiluminescence (ECL luminescence kit; Amersham Corp., Arlington Heights, IL). To quantify the amount of $o b$ protein in test samples, serial dilutions of sample along with several dilutions of purified $E$. coli $o b$ protein standards were run on the same gel, and band densities were compared by densitometry.

\section{Animal and tissue processing techniques}

Assay of $o b$ protein. All procedures involving animals were approved by the University of Washington Animal Care Committee. To measure the effect of $o b$ protein on 24-h food consumption, male $o b / o b$ mice obtained from Jackson Laboratories (Bar Harbor, ME) at 6-8 wk of age were caged individually and accustomized to daily 1-ml intraperitoneal injections of PBS given between 1000 and $1100 \mathrm{~h}$. Animals had continuous access to water and standard rodent chow blocks (Teklad, Madison, WI) which were weighed daily before injection. Room lights went off at $1100 \mathrm{~h}$ and came on at $2300 \mathrm{~h}$. Animals were monitored until they demonstrated steadily increasing body weight, and daily chow consumption varied by $<10 \%$ over a period of $3 \mathrm{~d}$ before a test injection. Chow consumption during the $24-\mathrm{h}$ period after a $1-\mathrm{ml}$ injection of test medium was expressed as a percentage of chow intake in response to PBS injection during the preceding 24-h period.

To examine longer term effects of $o b$ protein administration, test or control medium was given by daily $1-\mathrm{ml}$ intraperitoneal injection over a 2-wk period, and daily chow consumption and body weight were measured. Blood was obtained from the orbital sinus for measurement of serum insulin and glucose levels at $0900 \mathrm{~h} 1 \mathrm{~d}$ before and on the last day of the 2-wk injection period. Insulin was measured by radioimmunoassay using a human insulin standard, and glucose was measured by the hexokinase method (Sigma HK kit).

Adipose tissue culture. Epididymal, inguinal, dorsal, and retroperitoneal adipose tissue pads were removed from 12-14-wk-old nonfasted male $f a / f a$ rats (Harlan Sprague-Dawley Co., Indianapolis, IN), or 1014-wk-old nonfasted male $o b / o b$ or $d b / d b$ mice (Jackson Laboratories ) under metophane anesthesia, placed into room temperature Dulbecco's modified Eagle's medium containing 4.5 grams/liter glucose and 20 $\mathrm{mM}$ Hepes, and immediately dissected with sharp scissors into 10-15$\mathrm{mg}$ fragments. Tissue fragments were washed once in medium and then incubated in $150-\mathrm{mm}$ culture dishes for $3-5 \mathrm{~h}$ at $37^{\circ} \mathrm{C}$ in a $5 \% \mathrm{CO}_{2}$ atmosphere ( $2.5 \mathrm{ml}$ medium per gram of tissue). The dishes were rotated gently for $1 \mathrm{~min}$ every half hour. After incubation, adipose tissueconditioned medium was harvested and concentrated 30 -fold at a 1,000$\mathrm{D}$ cutoff in a sterile 76-mm ultrafiltration cell (YM-1 membrane; Amicon).

Northern analysis. RNA was prepared from 3 grams of epididymal adipose tissue collected from a nonfasted 16-wk-old male SpragueDawley rat, 1 gram of microdissected $o b / o b$ mouse epididymal adipose tissue fragments, or monolayers of transfected BHK cells in 100-mm 


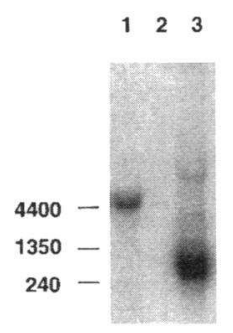

A

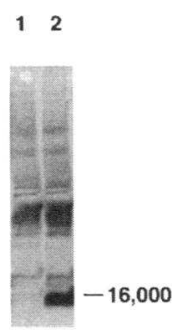

B

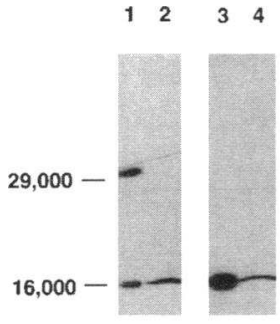

C

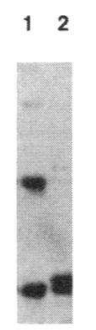

D
Figure 1. (A) Northern analysis of $o b$ message in $11 \mu \mathrm{g}$ of RNA from Sprague-Dawley rat epididymal adipose tissue (lane 1 ), $4 \mu \mathrm{g}$ of RNA from BHK cells transfected with Zem229R alone (lane 2 ), or $4 \mu \mathrm{g}$ of RNA from BHK cells cotransfected with Zem229R and pDX containing $o b$ coding region cDNA (lane 3 ). Size markers denote base pairs. ( $B$ ) Silver-stained reducing gel of hydroxyapatite column-purified medium conditioned by BHK cells transfected with Zem229R alone (lane 1 ) or BHK cells cotransfected with Zem229R and pDX containing $o b$ coding region cDNA (lane 2). (C)

Western analysis of $o b$ protein in culture medium conditioned by BHK cells expressing recombinant $o b$ protein (lanes $l$ and 3 ) or by $f a / f a$ rat adipose tissue (lanes 2 and 4 ). Lanes 1 and 2 were from a gel run under nonreducing conditions, and lanes 3 and 4 were from a gel run under reducing conditions. $(D)$ Western analysis under nonreducing conditions of $a b$ protein in recombinant BHK cell conditioned culture medium before (lane 1 ) and after (lane 2) hydroxyapatite column chromatography. Size markers for panels $B, C$, and $D$ denote atomic mass units.

culture dishes. Tissue or cells were homogenized in $4 \mathrm{M}$ guanidine thiocyanate, and RNA was prepared by the method of Chomczynski and Sacchi (18). After resuspension in Tris/EDTA, RNA was loaded onto $1 \%$ agarose gels, electrophoresed at $75 \mathrm{~V}$, and transferred to nitrocellulose filters. Filters were prehybridized for $2 \mathrm{~h}$ at $65^{\circ} \mathrm{C}$ in Rapidhyb solution (Amersham Corp.) followed by the addition of 1-1.5 $\times$ $10^{6} \mathrm{cpm} / \mathrm{ml}$ of ${ }^{32} \mathrm{P}$-labeled $o b \mathrm{cDNA}$ prepared by kit (Megaprime Labeling kit; Amersham Corp.). Filters were hybridized for $1 \mathrm{~h}$ at $65^{\circ} \mathrm{C}$, washed in $0.25 \times \mathrm{SSC} / 0.25 \% \mathrm{SDS} / 1 \mathrm{mM}$ EDTA at $65^{\circ} \mathrm{C}$, and imaged using a Molecular Dynamics PhosphorImager (Sunnyvale, CA).

\section{Statistics}

All results were expressed as mean \pm standard error (SE), and comparisons were made using two-tailed paired or unpaired $t$ tests, as appropriate, with a significance level of $0.05 \%$.

\section{Results}

Northern analysis was performed to verify successful cotransfection of BHK cells with plasmids containing cDNA for the $o b$ protein and selectable marker. No $o b$ message was detected in control BHK cells transfected with ZEM229R alone, whereas a high level of $o b$ mRNA was evident in cells transfected with both ZEM22R and the pDX $o b$ vector (Fig. $1 A$ ). The smaller size of $o b$ mRNA in the BHK system compared with message detected in rat adipose tissue (Fig. $1 A$ ) reflects deletion of the $o b$ cDNA $3^{\prime}$ untranslated region in the recombinant construct. A silver-stained reducing gel of hydroxyapatite column-purified medium conditioned by control and recombinant BHK cells is shown in Fig. $1 \mathrm{~B}$. The protein profile of the two types of media is identical except for the presence of $o b$ protein which

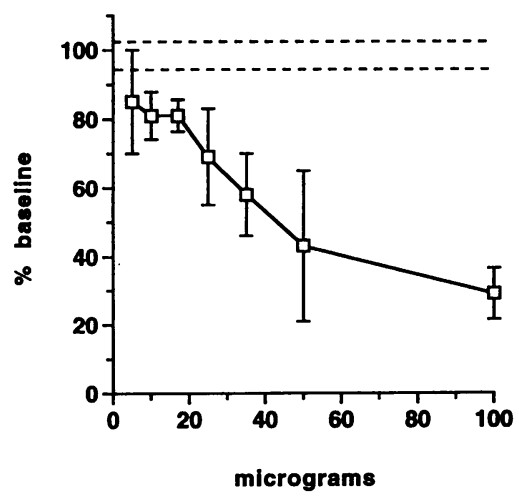

Figure 2. Effect of a single intraperitoneal injection of recombinant $o b$ protein on 24-h chow consumption by $o b / o b$ mice. Results are expressed as percentage of baseline 24-h chow consumption after injection of an equal volume of PBS. The area between the dashed lines represents the effect of identically processed nonrecombinant control me-

dium (mean $\pm \mathrm{SE}$ ) on feeding in nine mice. Points represent mean $\pm \mathrm{SE}$ of three mice for each $o b$ protein dose.

represents $63 \%$ of the total protein in purified medium conditioned by recombinant BHK cells. Western analyses performed on both nonreducing and reducing gels of unprocessed media conditioned by recombinant BHK cells are shown in Fig. $1 C$. It can be seen that both monomeric and dimeric forms of $o b$ protein are produced, whereas only the monomeric form of mature $16-\mathrm{kD} o b$ protein is evident in medium conditioned by microdissected $\mathrm{fa} / \mathrm{fa}$ rat adipose tissue. Western analysis of recombinant BHK cell conditioned medium before and after hydroxyapatite column purification is shown in Fig. $1 \mathrm{D}$. This purification step removes dimeric $o b$ protein, resulting in material that more closely resembles the naturally produced $o b$ gene product.

Hydroxyapatite column-purified monomeric BHK $o b$ protein decreased 24-h chow consumption by $o b / o b$ mice (Fig. 2 ). A progressive reduction of chow intake from baseline was seen with increasing dosage of protein. The difference in response to injections of $o b$ protein and injections of ZEM229R control conditioned medium became significant at a dose of 10 $\mu \mathrm{g}(81 \pm 6.8 \%$ of control, $P=0.04)$ and appeared to be nearly maximal at a dose of $100 \mu \mathrm{g}(29 \pm 7.7 \%$ of control, $P<0.0001)$. Administration of purified dimeric $o b$ protein at doses of 10 $25 \mu \mathrm{g}$ produced an insignificant decrease in feeding to $98 \pm 4.4 \%$ of baseline $(n=5)$.

If hyperphagia and obesity in the $o b / o b$ mouse are due to lack of functional $o b$ protein, and the normal route by which the $o b$ protein acts is through the circulation, then chronic administration of recombinant $o b$ protein should lead to reductions in feeding and body weight in $o b / o b$ mice. These predictions were verified during 2 wk of daily $o b$ protein injections (Fig. $3 A)$, with an $11 \pm 1.6 \%$ decrease in body weight $(P=0.0009)$ and a maximal suppression of feeding to $26 \pm 4.9 \%$ of baseline $(P<0.0001)$. The effect of injections on chow intake and body weight dissipated rapidly after the test period. Daily injection of ZEM229R conditioned medium to control animals had no effect on feeding or weight gain (Fig. $3 B$ ). Serum insulin and glucose levels decreased significantly after 2 wk of $o b$ protein administration in test animals, but remained elevated in control animals (Table I).

To determine whether the effect of $o b$ protein is enhanced by interaction with other adipocyte secretory products, microdissected $o b / o b$ mouse adipose tissue was incubated in medium previously conditioned by either control BHK cells or BHK cells producing recombinant $o b$ protein. An equal ratio of adipose tissue to media was used in both incubations, and the 

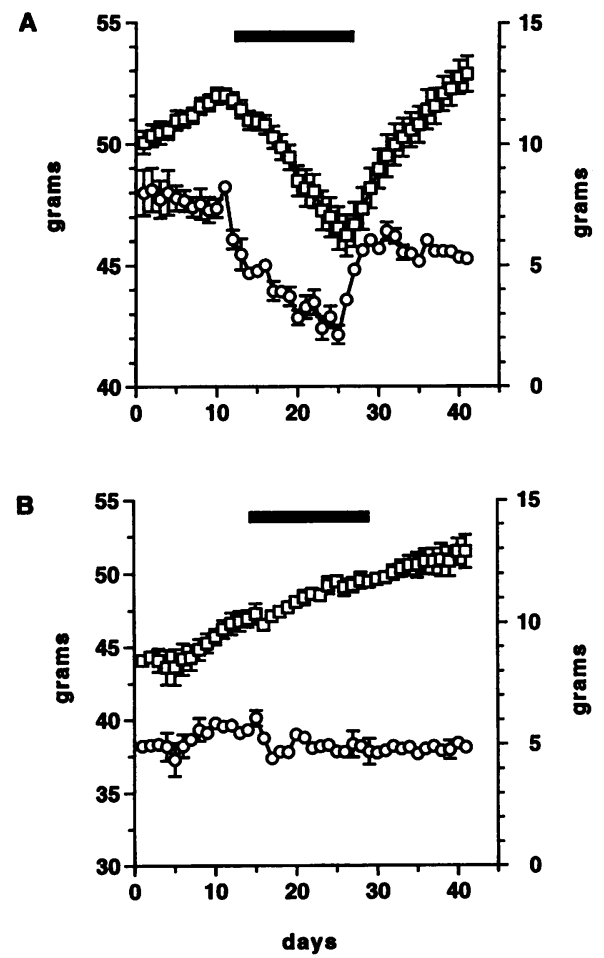

Figure 3. Effect of daily administration of recombinant $o b$ protein or control medium on body weight (squares, left axes) and chow consumption (circles, right axes) of $o b / o b$ mice. Animals received daily 1-ml injections of PBS except during the periods indicated by the bars when injections were changed to $80 \mu \mathrm{g}$ of recombinant $o b$ protein in $1 \mathrm{ml}$ of medium $(A, n=6)$ or $1 \mathrm{ml}$ of equally concentrated nonrecombinant control medium $(B, n=3)$. All points represent mean $\pm \operatorname{SE}$ (some error bars are hidden within symbols).

volumes were chosen such that a comparable amount of recombinant BHK cell conditioned medium would produce a measurable but submaximal response in the feeding assay after our standard 30-fold concentration. Microdissected adipose tissue from the $d b / d b$ mouse, which produces circulating adiposerelated satiety factor $(9,10)$, was incubated in the same volume ratio of unconditioned medium and used as a control to assure physiological secretory function of adipose tissue under the chosen experimental conditions. Incubation of $o b / o b$ mouse adipose tissue in medium containing recombinant $o b$ protein did not enhance the ability of that medium to suppress feeding in test animals (Table II). Medium conditioned by $d b / d b$ mouse adipose tissue produced a significant feeding suppression which exceeded the response observed to medium conditioned by $o b /$

Table I. Changes in Insulin and Glucose Levels after 2 wk of Daily ob Protein or Control Medium Injections

\begin{tabular}{cccccccc}
\hline & \multicolumn{3}{c}{ Insulin (ng/ml) } & & \multicolumn{3}{c}{ Glucose (mg/d) } \\
\cline { 2 - 4 } \cline { 7 - 8 } Injectate & Day 14 & Day 28 & $P$ & & Day 14 & Day 28 & $P$ \\
\hline $\begin{array}{c}o b \text { protein } \\
(n=6)\end{array}$ & $122 \pm 11$ & $10 \pm 1.9$ & 0.0002 & $489 \pm 44$ & $167 \pm 8.9$ & 0.0007 \\
$\begin{array}{c}\text { Control } \\
(n=3)\end{array}$ & $427 \pm 114$ & $275 \pm 68$ & NS & $427 \pm 81$ & $448 \pm 87$ & NS \\
\hline
\end{tabular}

Results are expressed as mean $\pm \mathrm{SE}$
Table II. Effect of ob Protein-containing Medium on 24-h Chow Intake after Conditioning by Microdissected Adipose Tissue

\begin{tabular}{cccccc}
\hline \multicolumn{2}{c}{ Incubation conditions } & & $\begin{array}{c}\text { Response (percentage of } \\
\text { baseline 24-h chow } \\
\text { intake) }\end{array}$ & $P$ \\
\cline { 1 - 2 } $\begin{array}{c}\text { Adipose tissue } \\
\text { donor strain }\end{array}$ & Medium & $n$ & $74 \pm 2.9$ & NS \\
\hline None & BHK $o b$ protein & 9 & $75 \pm 1.6$ & \\
$o b / o b$ & BHK $o b$ protein & 5 & $90 \pm 4.8$ & 0.045 \\
$o b / o b$ & Control & 5 & $72 \pm 5.5$ & \\
$d b / d b$ & Control & 4 & & \\
\hline
\end{tabular}

Results are expressed as mean $\pm \mathrm{SE}$.

$o b$ mouse adipose tissue. In a separate experiment, equal amounts of microdissected $o b / o b$ mouse adipose tissue were placed into either control culture medium or 30 -fold concentrated medium conditioned by BHK cells producing recombinant $o b$ protein. After $6 \mathrm{~h}$ of incubation, RNA was prepared from the tissue fragments, and $o b$ message level was assessed by Northern analysis. $o b$ mRNA levels did not differ appreciably in adipose tissue exposed to control culture medium or medium containing recombinant $o b$ protein at a concentration sufficient to produce significant appetite suppression (Fig. 4).

To determine whether posttranslational processing by a mammalian cell is essential for activity, recombinant $o b$ protein cleaved from the $E$. coli fusion product and refolded in vitro was administered to nine $o b / o b$ assay animals at a dose of 50 $\mu \mathrm{g}$ per animal. This material produced a suppression of $24-\mathrm{h}$ chow consumption to $70 \pm 3.2 \%$ of baseline as compared with $101 \pm 4.1 \%$ of baseline observed in nine animals that received control buffer injections $(P<0.0001)$. Amino-terminal hexahistidine-tagged recombinant BHK cell $o b$ protein that had been purified to near homogeneity over a nickle column was also assayed. The latter material at a dose of $25 \mu \mathrm{g}$ suppressed 24h chow consumption to $70 \pm 6.2 \%$ of baseline $(n=6)$ as compared with $100 \pm 4.0 \%$ of baseline in six animals that received control buffer injections $(P=0.002)$. The effect of a single injection of tagged $o b$ protein on feeding was significantly pro-

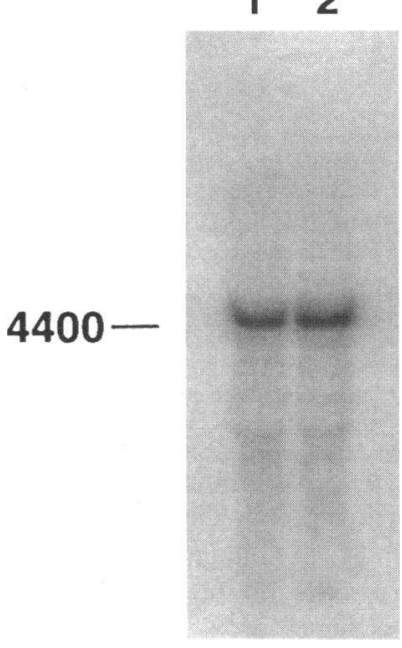

Figure 4. Northern analysis of $o b$ message in $11 \mu \mathrm{g}$ of RNA from microdissected $o b / o b$ adipose tissue that had been cultured for $6 \mathrm{~h}$ in 30-fold concentrated medium conditioned by BHK cells producing recombinant $o b$ protein (lane 1) or nonrecombinant control medium (lane 2). 


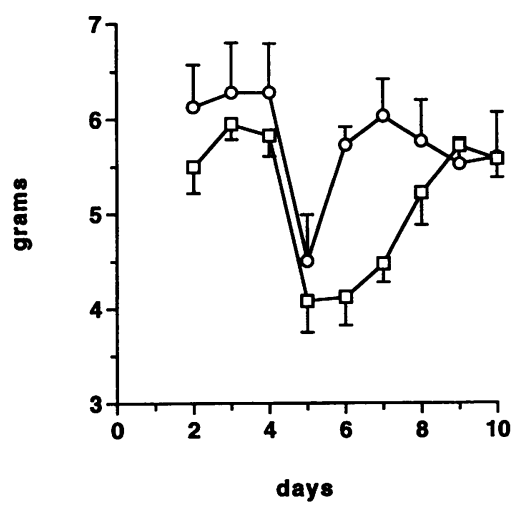

Figure 5. Prolonged feeding suppression in six $o b / o b$ mice that received single $25-\mu \mathrm{g}$ injections of amino-terminal hexahistidine-tagged $o b$ protein on day 4 (squares) as compared to six animals that received $25 \mu \mathrm{g}$ of unmodified recombinant $o b$ protein (circles). Results are expressed as grams of chow consumed in $24 \mathrm{~h}$ (mean $\pm \mathrm{SE})$.

longed relative to the effect of unmodified $o b$ protein produced by BHK cells (Fig. 5).

\section{Discussion}

Abundant evidence from animal experimentation suggests that a stable circulating adipose-related satiety factor plays an important role in the regulation of body fat content (6). This factor could be a molecule such as insulin that circulates at a level proportional to total adipose mass but is not produced by adipocytes (19). Alternatively, adipocytes could directly secrete a substance that inhibits feeding when the total body triglyceride store becomes excessive. Support for the latter hypothesis has been limited by the technical difficulty of using feeding behavior as an assay to guide purification of the putative molecule from adipose tissue $(11,12)$. The protein product of the recently cloned $o b$ gene is an excellent candidate for an adipose-related satiety factor by virtue of its predicted structural features and natural source $(13,14)$. The goals of the present study were to produce recombinant $o b$ protein in sufficient quantity to assess its effect on feeding and body weight and to explore the possibility that posttranslational processing or cofactors produced by adipose tissue were required for any observed activity.

With regard to the first goal, expression of $o b$ protein by recombinant BHK cells was sufficient to demonstrate immunoreactive protein in unconcentrated conditioned culture medium and bioactive protein after 10-30-fold concentration of conditioned medium by ultrafiltration. Western analysis of recombinant BHK medium under reducing and nonreducing conditions demonstrated both mature $o b$ protein of $16 \mathrm{kD}$ and a species of $32 \mathrm{kD}$ consistent with disulfide bond formation between two $o b$ molecules. Broad bands or doublets occasionally seen by Western analysis suggested the existence of additional conformational forms of $o b$ protein, but the agreement between observed and calculated molecular weights argued against extensive glycosylation. Although concentrated recombinant BHK medium suppressed feeding in $o b / o b$ mice without further processing, monomeric $o b$ protein appeared to be the predominant form secreted by cultured $f a / f a$ rat adipose tissue. Accordingly, hydroxyapatite chromatography was used to remove dimeric $o b$ protein from conditioned medium before performing feeding dose-response studies.

Animals were required to display a daily variation in 24-h chow intake of $10 \%$ or less for inclusion in the current feeding assay. A difference in chow intake of up to $20 \%$ would, therefore, be expected in response to the same material given on two separate occasions even if all other variables affecting feeding were constant. Despite this inherent imprecision, recombinant $o b$ protein clearly inhibited 24-h chow intake by $o b / o b$ mice in a dose-dependent manner. All animals used in the feeding assay remained active, groomed normally, and demonstrated steady weight gain after test injections, suggesting that the observed decreases in chow consumption were not due to toxicity of the $o b$ protein preparation. Formal testing for an aversive effect of injectate was not performed since $o b$ protein is produced physiologically by adipose tissue, and identically processed medium conditioned by BHK cells transfected only with the nonrecombinant ZEM229R plasmid had no effect in the assay. The possibility that decreases in feeding reflected an immune response of sensitized animals to injected $o b$ protein was excluded by the observation of significant feeding suppression in animals receiving test injections for the first time. It has not yet been technically possible to compare the circulating $o b$ protein levels achieved after intraperitoneal injections in assay animals to naturally occurring levels in nonobese mice.

2 wk of daily $o b$ protein injections resulted in progressive weight loss in assay animals as expected if the $o b$ protein defect is the direct cause of obesity in the $o b / o b$ mouse, and the protein exerts its effect outside the cell of origin. The animals were not killed to measure body fat content at the end of the 2-wk study period since it was felt important to verify that return to baseline weight began immediately after discontinuation of test injections as a sign that treatment produced no ill effects. Undoubtedly some fat free mass was lost along with adipose tissue as a result of treatment (20), but activity levels and apparent wellbeing of the assay animals appeared unchanged or even improved. The highly significant decreases in both insulin and glucose levels in animals that received test injections demonstrated that improved insulin sensitivity accompanied the weight loss induced by recombinant $o b$ protein. Although the cumulative reduction in chow intake appeared to account for most of the weight loss observed in test animals, it is possible that an increase in thermogenesis induced by $o b$ protein administration contributed to the negative energy balance.

In rodents that have undergone weight loss as a result of food restriction, marked hyperphagia is observed immediately after return to ad libitum feeding and persists until body weight has been completely regained (21). The notable absence of rebound hyperphagia after $2 \mathrm{wk}$ of $o b$ protein administration in the current study indicates that the effect of $o b$ protein is actually much more sustained than Fig. 3 would suggest. To the extent that satiety and hunger are mediated by separate pathways in the central nervous system, it is possible that, in addition to inducing satiety, $o b$ protein suppresses the activation of a hunger system that would ordinarily occur with food restriction. Our observations might be explained by a reduction in hypothalamic neuropeptide Y levels $(22,23)$ in animals chronically treated with $o b$ protein.

The ability of injected recombinant $o b$ protein to reduce feeding and body weight in assay animals does not exclude the possibility that naturally produced $o b$ protein is more active by virtue of modification within the adipocyte or association with a secreted adipocyte-derived cofactor. It is also possible that the $o b$ protein is not itself a satiety factor but that it acts locally within adipose tissue or indirectly on another tissue type to cause the release of such a factor. The culture of microdissected $o b / o b$ adipose tissue fragments in medium containing recombinant $o b$ protein was designed to examine some of these possibilities. The volume of recombinant medium and amount of cultured adipose tissue were chosen such that after concentration 
each would reduce 24 -h chow intake to $\sim 70-75 \%$ of baseline if studied independently. Since our assay could detect reductions of 24-h chow intake down to $29 \%$ of baseline, enhancement of the effect of recombinant $o b$ protein due to an interaction with $o b / o b$ mouse adipose tissue should have been easily detected. Our failure to detect synergism in this experiment argues against the requirement for a secreted adipocyte-derived cofactor or a local mechanism of action of $o b$ protein. Our data do not exclude the possibility that modification of $o b$ protein before secretion by the adipocyte could lead to greater activity than can be achieved by expression in BHK cells. The reduced satiety activity of medium conditioned by $o b / o b$ adipose tissue relative to that conditioned by $d b / d b$ adipose tissue is consistent with the defective $o b$ gene in the $o b / o b$ mouse and suggests that the $o b$ protein is the circulating satiety signal identified in the parabiosis studies of Coleman and Hummel $(9,10)$.

It has been reported that the $o b$ mRNA level in $o b / o b$ mouse fat is greatly increased relative to the level observed in fat of lean littermates (13). This could be due to linkage of $o b$ gene transcription to fat cell size or triglyceride synthesis by metabolic signals yet to be described. Alternatively, there could be release of end product inhibition of $o b$ gene transcription in the $o b / o b$ mouse due to the production of a defective $o b$ protein. The latter possibility suggests that the $o b$ protein might interact with a receptor on the adipocyte to alter its own level of expression. Our failure to detect any alteration in $o b$ mRNA level in adipose tissue fragments cultured in the presence of recombinant $o b$ protein argues against such an autocrine feedback mechanism. The possibility that intracellular $o b$ protein might downregulate $o b$ gene transcription cannot be excluded by our data.

The finding that recombinant $o b$ protein produced in a prokaryotic system retains the ability to suppress feeding demonstrates that posttranslational modification by a mammalian cell is not absolutely required for activity. The lower activity of $o b$ protein produced by $E$. coli relative to BHK cells may reflect incorrect refolding of a portion of the prokaryotic material during the reoxidation step. Addition of a hexahistidine tag to the amino terminus of the $o b$ protein created the possibility of a onestep purification of recombinant material over a metal chelation column. Rather than inactivating the molecule, this modification resulted in a prolonged suppression of feeding after administration to $o b / o b$ mice. The altered kinetics of the response to tagged $o b$ protein might be due to resistance to degradation in the serum or stabilization of the interaction of $o b$ protein and its receptor.

Our results demonstrate a direct effect of the $o b$ protein to suppress feeding and suggest that this molecule plays a critical role in regulating total body fat content. If the circulating $o b$ protein level proves to be the dominant signal interpreted by the central nervous system to reflect energy stores, then exogenous administration of this substance may be useful in treating some forms of human obesity. Recent reports that adipocyte $o b$ mRNA levels are elevated in obese rats (24) and humans (25) raise the possibility that obesity is accompanied by a relative insensitivity to the $o b$ protein. Therapeutic use of exogenous $o b$ protein may, therefore, not be possible in all individuals or may require large doses of protein to overcome resistance to this agent at a receptor or postreceptor level.

\section{Acknowledgments}

We wish to acknowledge the expert technical assistance of Cameron Brandt, Darlene Celino, Andrew Ching, Nancy Jenkins, Nancy Porrelli, Deborah Puerner, Mariya Sweetwyne, Angie Swenson, Ramel Velasco, and Laurie Wilcox. We are also deeply indebted to Craig Bailey, Paul Bishop, John Forstrom, Frank Grant, Steve Jaspers, Si Lok, and Gary McKnight for their creative insights in this project and to John Brunzell for reviewing the manuscript.

\section{References}

1. Hubert, H. B., M. Feinleib, P. M. McNamara, and W. P. Castelli. 1983. Obesity as an independent risk factor for cardiovascular disease: a 26-year followup of participants in the Framingham Heart Study. Circulation. 67:968-977.

2. Lindsted, K., S. Tonstad, and J. W. Kuzma. 1991. Body mass index and patterns of mortality among Seventh-day Adventist men. Int. J. Obes. 15:397406

3. Keesey, R. E., and T. L. Powley. 1986. The regulation of body weight. Annu. Rev. Psychol. 37:109-133.

4. Mrosovsky, N. 1986. Body fat: what is regulated? Physiol. \& Behav. 38:407-414.

5. Weigle, D. S. 1991. The pathophysiology of obesity: implications for treatment. Endocrinologist. 1:385-392.

6. Weigle, D. S. 1994. Appetite and the regulation of body composition. FASEB (Fed. Am. Soc. Exp. Biol.) J. 8:302-310.

7. Kennedy, G. C. 1953. The role of depot fat in the hypothalamic control of food intake in the rat. Proc. R. Soc. Lond. B. Biol. Sci. 140:578-592.

8. Hervey, G. R. 1959. The effects of lesions in the hypothalamus in parabiotic rats. J. Physiol. 145:336-352.

9. Coleman, D. L. 1973. Effects of parabiosis of obese with diabetes and normal mice. Diabetologia. 9:294-298.

10. Coleman, D. L., and K. P. Hummel. 1969. Effects of parabiosis of normal with genetically diabetic mice. Am. J. Physiol. 217:1298-1304.

11. Hutson, A. M., G. E. Meyer, and D. S. Weigle. 1992. Bioassay for a satiety factor produced by adipose tissue from overfed obese rats. Clin. Res. 40:60a. (Abstr.)

12. Hulsey, M. G., and R. J. Martin. 1992. An anorectic agent from adipose tissue of overfed rats: effects on feeding behavior. Physiol. \& Behav. 52:11411149.

13. Zhang, Y., R. Proenca, M. Maffei, M. Barone, L. Leopold, and J. M. Friedman. 1994. Positional cloning of the mouse obese gene and its human homologue. Nature (Lond.). 372:425-432.

14. Rink, T. J. 1994. In search of a satiety factor. Nature (Lond.). 372:406407.

15. Bray, G. A., and D. A. York. 1979. Hypothalamic and genetic obesity in experimental animals: an autonomic and endocrine hypothesis. Physiol. Rev. 59:719-809.

16. Foster, D. C., M. S. Rudinski, B. G. Schach, K. L. Berkner, A. A. Kumar, F. S. Hagen, C. A. Sprecher, M. Y. Insley, and E. W. Davie. 1987. Propeptide of human protein $\mathrm{C}$ is necessary for gamma-carboxylation. Biochemistry. 26:7003-7011.

17. Graham, F. L., and A. J. Van der Eb. 1973. A new technique for the assay of infectivity of human adenovirus 5 DNA. Virology. 52:456-467.

18. Chomczynski, P., and N. Sacchi. 1987. Single-step method of RNA isolation by acid guanidinium thiocyanate-phenol-chloroform extraction. Anal. Biochem. 162:156-159.

19. Porte, D., Jr., and S. C. Woods. 1981. Regulation of food intake and body weight by insulin. Diabetologia. 20:274-279.

20. Harris, R. B. S., and R. J. Martin. 1984. Recovery of body weight from below "set point" in mature female rats. $J$. Nutr. 114:1143-1150.

21. Harris, R. B. S., T. R. Kasser, and R. J. Martin. 1986. Dynamics of recovery of body composition after overfeeding, food restriction or starvation of mature female rats. J. Nutr. 116:2536-2546.

22. Kalra, S. P., M. G. Dube, A. Sahu, C. Phelps, and P. S. Kalra. 1991 Neuropeptide $\mathrm{Y}$ secretion increases in the paraventricular nucleus in association with increased appetite for food. Proc. Natl. Acad. Sci. USA. 88:10931-10935. 23. Stanley, B. G., S. E. Kyrkouli, S. Lampert, and S. F. Leibowitz. 1986. Neuropeptide Y chronically injected into the hypothalamus: a powerful neurochemical inducer of hyperphagia and obesity. Peptides. 7:1189-1192

24. Murakami, T., and K. Shima. 1995. Cloning of rat obese cDNA and its expression in obese rats. Biochem. Biophys. Res. Commun. 209:944-952.

25. Considine, R. V., E. L. Considine, C. J. Williams, M. R. Nyce, S. A. Magosin, T. L. Bauer, E. L. Rosato, J. Colberg, and J. F. Caro. 1995. Evidence against either a premature stop codon or the absence of obese gene mRNA in human obesity. J. Clin. Invest. 95:2986-2988. 